Studies in Fungi 2 (1): 119-129 (2017) www.studiesinfungi.org ISSN 2465-4973

Article

Doi 10.5943/sif/ 2/1/14

Copyright $\odot$ Mushroom Research Foundation

\title{
Endophytic Mycodiversity of Sacred Tree - Couroupita guianensis Aubl.
}

\author{
Velmurugan $\mathbf{R}^{1}$, Ramesh $\mathrm{V}^{2}$, Meenatchi $\mathrm{A}^{3}$, Bagyalakshmi ${ }^{3}$ and Rajendran $\mathrm{A}^{3^{*}}$ \\ ${ }^{1}$ Department of Botany, Saiva Bhanu Kshatriya College, Aruppukottai - Tamilnadu, India 626101. \\ ${ }^{2}$ Department of Botany, Vivekananda College (Autonomous), Tiruvedagam West, Tamilnadu, India - 625234. \\ ${ }^{3}$ Department of Botany, Virudhunagar Hindu Nadar's Senthilkumara Nadar College, Virudhunagar -626 001.
}

Velmurugan R, Ramesh V, Meenatchi A, Bagyalakshmi, Rajendran A 2017 - Endophytic Mycodiversity of Sacred Tree - Couroupita guianensis Aubl. Studies in Fungi 2(1), 119-129, Doi $10.5943 / \mathrm{sif} / 2 / 1 / 14$

\begin{abstract}
In the present study, a total of 142 fungal strains were isolated from 180 samples of the leaf, stem and bark tissues of sacred tree Couroupita guianensis from an unusual semi-arid tropical region. The tissues of the samples were grown in potato dextrose agar (PDA) medium and the endophytic mycoflora were identified based on the morphological characteristics. Among all the strains, 130 were fertile, which belong to 11 species and 12 sterile morpho species. The relative frequency of isolated individual endophytic fungal group consists of hyphomycetes (41.5\%), coelomycetes (32.4\%), ascomycetes (13.4\%), zygomycetes (4.2\%) and sterile fungi (8.5\%). Among the fungal isolates, Scytalidium acidophilum and Mycosphaerella sp. were recorded as the most dominant fungal isolates in the leaf tissues, Cladosporium cladosporioides and Colletotrichum falcatum were observed as the dominant endophytic fungal isolates in the stem tissues and Botryodiplodia theobromae was found to be predominant species in bark tissues of $C$. guianensis. The species of Colletotrichum were found only in stem tissues. Therefore, the endophytic mycodiversity were high and abundant and they were distinctly associated with host plant. All statistical analyses confirmed that leaf tissues contained more endophytes than the stem and bark while Colletotrichum exhibited organ specificity. The present study revealed that the sacred tree $C$. guianensis is one of the ecological niches for sheltering endophytic mycoflora eventhough in harsh climatic conditions.
\end{abstract}

Key words - Colletotrichum - PDA organ specificity - semi-arid region - tropical region

\section{Introduction}

Couroupita guianensis is an ever green tropical forest tree that belonging to the family Lecythidaceae, commonly known as cannonball tree. It is native to the Amazon rainforests of Central and South America and also seen in India, especially in the southern states of Western Ghats (Savinaya et al. 2016). Leaves are simple and clustered; flowers are showy with a ring of stamens like hood. In India this tree is sacred to Hindus, who believe its hooded flowers look like the naga (Snake), and it is grown at Shiva temples. Plants associated with temples are sacred trees that possess supernatural power and are preserved and protected by the local people on religious basis over a period of time in Sacred Groves or "Gardens of Gods" and also in their region. The plants growing on arid land contain some functional components that protect them from their stress 
habitat in which the endophytes may also possess novel strategies for their survivability. The sacred tree has several medicinal properties like antimicrobial, antimycobacterial and antibiofilm and used to treat the common cold, malaria, stomachache, toothache, hypertension, skin infections, wounds, tumors, pain and inflammation (Jayapal et al. 2014)

Endophytes are the part of the microbial community found in all species of plant (Arnold et al. 2000) that include bacteria, fungi, actinomycetes and mycoplasma (Bandara et al. 2006) which live inside plant tissue for at least a part of their life cycle without causing any disease symptoms in the host (Petrini 1991). The most frequently encountered endophytes are fungi (Staniek et al. 2008). Plants may serve as a reservoir of large number of endophytic fungi (Bacon \& White 2000). Research of biodiversity of endophytic fungi has a long history and their diversity among plants has been found to be considerably large with reliable source of genetic diversity and novel undescribed species. Endophytic fungi are known to harbour compounds beneficial for plant health as well as human health which can produce various bioactive chemicals (Tejesvi et al. 2011), that promote host growth and resistance to environmental stress (Saikkonen et al. 2010) and also serve as potential sources of novel natural products for exploitation in medicine, agriculture, and industry (Strobel \& Daisy 2003). Since natural products are adapted to a specific function in nature, the search for novel secondary metabolites should concentrate on organisms that inhabit novel biotopes. An endophytic fungus inhabits such a biotope. The isolation of novel secondary metabolites from the endophytes is an important aspect of present day research. The present study was carried out to determine the endophytic mycoflora associated with Couroupita guianensis, a rarely occurring sacred tree in semi-arid region.

\section{Materials \& Methods}

\section{Collection of plant material}

A total of 180 segments of leaf stems and bark tissues of 60 each from the Couroupita guianensis Aubl. (Lecythidaceae) were collected from the semi-arid tropical region of Virudhunagar district, Tamil Nadu, India. Those were used for the investigation of endophytic fungal communities. The samples were taken 3-4 feet above the ground level of tree and brought to the laboratory in sterile polythene bags and then inoculated within $3 \mathrm{~h}$ of collection.

\section{Isolation and identification of endophytic fungi}

Isolation of endophytic fungi was standardized and modified based on the method described by Hallman et al. (2007). The samples were washed with running tap water to remove dust, soil and debris adhering to them and surface sterilized with $70 \%$ ethyl alcohol and $4 \%$ sodium hypochlorite to remove adhering microorganisms. Finally the samples were rinsed with deionized double distilled sterile water to remove the surface sterilization agents and dried on sterile tissue papers in a laminar air flow chamber. The leaves and the inner bark tissue were cut in to segments in $3 \times 3$ $\mathrm{mm}^{2}$ size and 3-5 mm thickened respectively. Stem was also cut in to segments of $1 \mathrm{~mm}$ thickness under aseptic conditions using a sterile knife and scalpel. Five sterilized leaf, stem or bark segments were placed in a petridish containing Potato Dextrose Agar medium (PDA) supplemented with the antibiotic streptomycin sulfate $0.4 \mathrm{mg} / \mathrm{mL}$ to arrest bacterial growth. The petridishes were sealed with parafilm and incubated at $25 \pm 2{ }^{\circ} \mathrm{C}$ for 15 days under dark conditions and monitored the growth of endophytic fungal mycelium in every day. After 15 days, individual fungal colonies growing out of the explants were sub-cultured on separate PDA petri plates for pure cultures at room temperature and identified in their sporulation stage from 8-15 days. The fungi which failed to sporulate were designated as "mycelia sterilia". The morphological characters of the fungal isolates were observed and described according to the method of Photita et al. (2004). Morphological identification was done according to the standard taxonomic key included colony diameter, texture, color, morphology of hyphae and conidia (Anisworth et al. 1973). Finally, the endophytic fungal isolates were transferred separately to PDA slants and maintained at $4^{\circ} \mathrm{C}$ for further study. 


\section{Statistical analysis of endophytic fungi}

The Relative Frequency (RF) of isolation, used to represent fungal density, was calculated as the number of isolates of one fungal group divided by the total number isolates, and also expressed as percentage (Photita et al. 2001). The Colonization Frequency (CF \%) was used to compare diversity and it was calculated by using the method of Gond et al. (2007). The Colonization Frequency $(\mathrm{CF} \%)$ of a single endophytic species was calculated using Equation, $\mathrm{CF} \%=(\mathrm{Ncol} /$ $\mathrm{Nt}) \mathrm{X} 100$ where, $\mathrm{Ncol}=$ number of segments colonized by each fungus and $\mathrm{Nt}=$ total number of segments studied. Similarly the percentage frequency of dominant endophytes was calculated as the number of endophytic fungal colonies divided by total number of all endophytic fungal colonies (Mahesh et al. 2005). The Colonization Rate (CR \%) was used for the comparison of endophytic fungi in different tissues of given sample. The colonization rate was calculated as the total number of segments colonized by endophytic fungi divided by the total number of segments incubated for that plant sample, and expressed as percentage (Petrini et al. 1982). The Isolation Rate (IR) of endophytic fungi was used to measure the fungal richness in different tissues. The isolation rate was calculated as the number of isolates obtained from segments divided by the total number segments, but not expressed as percentage (Petrini \& Fisher 1988). Different diversity parameters were calculated using PAST - Paleontological Statistics Software Packages, ver. 3.05. The Simpson's diversity (1-D) was used to estimate the abundance of endophytes and Shannon-Wiener Diversity index $\left(\mathrm{H}^{\prime}\right)$ and Fisher's alpha index were analyzed to determine the species diversity of fungal endophytes colonized in leaf, stem and bark and the Evenness index that used to expresses the distribution of individual among the other endophytic fungi in every part of plant.

\section{Results}

Altogether 142 endophytic fungal isolates were obtained from 180 samples of leaf, stem and bark tissue of Couroupita guianensis. Among the isolates, 130 were fertile which belong to 11 species, and they consisted of 4 hyphomycetes, 5 coelomycetes, 1 ascomycetes, 1 zygomycetes and 12 non sporulating sterile morphospecies. The endophytic fungi were identified based on the colony morphology and sporulating structures. The fertile fungal isolates were Botryodiplodia theobromae, Cladosprium cladosporioides, Colletotrichum dematium, C. falcatum, C. truncatum, Fusarium moniliforme, F. oxysporum, Mycosphaerella sp., Mucor racemosus, Phyllosticta hymanaeae and Scytalidium acidophilum,

In the present study, the distribution of endophytic fungi in leaf, stem and bark tissues were investigated for the assemblage, tissue specificity, diversity and abundance. Endophytic fungi may inhabit all available tissues, some endophytic fungi preferred to colonize in the leaves and other endophytic fungi may colonize the tissue of other organs of the plant. Among 142 endophytic fungal isolates, 54 isolates were recovered from the leaves, 48 from stem and 40 from bark tissue of C. guianensis. The isolates of Botryodiplodia, Fusarium, Mycosphaerella and Scytalidium were reported to be higher in leaf than stem and bark. The isolates of Cladosporium isolated from stem were found to be higher than in the leaf and bark. Endophytic fungal strains of Colletotrichum showed tissue specificity that was only isolated from the stem (Table 3). The Relative Frequency (RF) of isolated individual endophytic fungal group belonged to hyphomycetes (41.5\%), coelomycetes $(32.4 \%)$, ascomycetes $(13.4 \%)$, zygomycetes $(4.2 \%)$ and non sporulating sterile form $(8.5 \%)$ from leaf, stem and bark tissues of $C$. guianensis (Table 1 \& Fig. 1).

In this study, the overall colonization frequency of endophytic fungal isolates in leaf was found to be $90 \%$ as highest when compared to stem $(79.8 \%)$ and bark $(66.6 \%)$ tissue. The colonization frequency of Cladosporium cladosporioides was $10 \%$ in stem and $8.3 \%$ in leaf and bark respectively. Among the species of Fusarium, the colonization frequency of Fusarium 


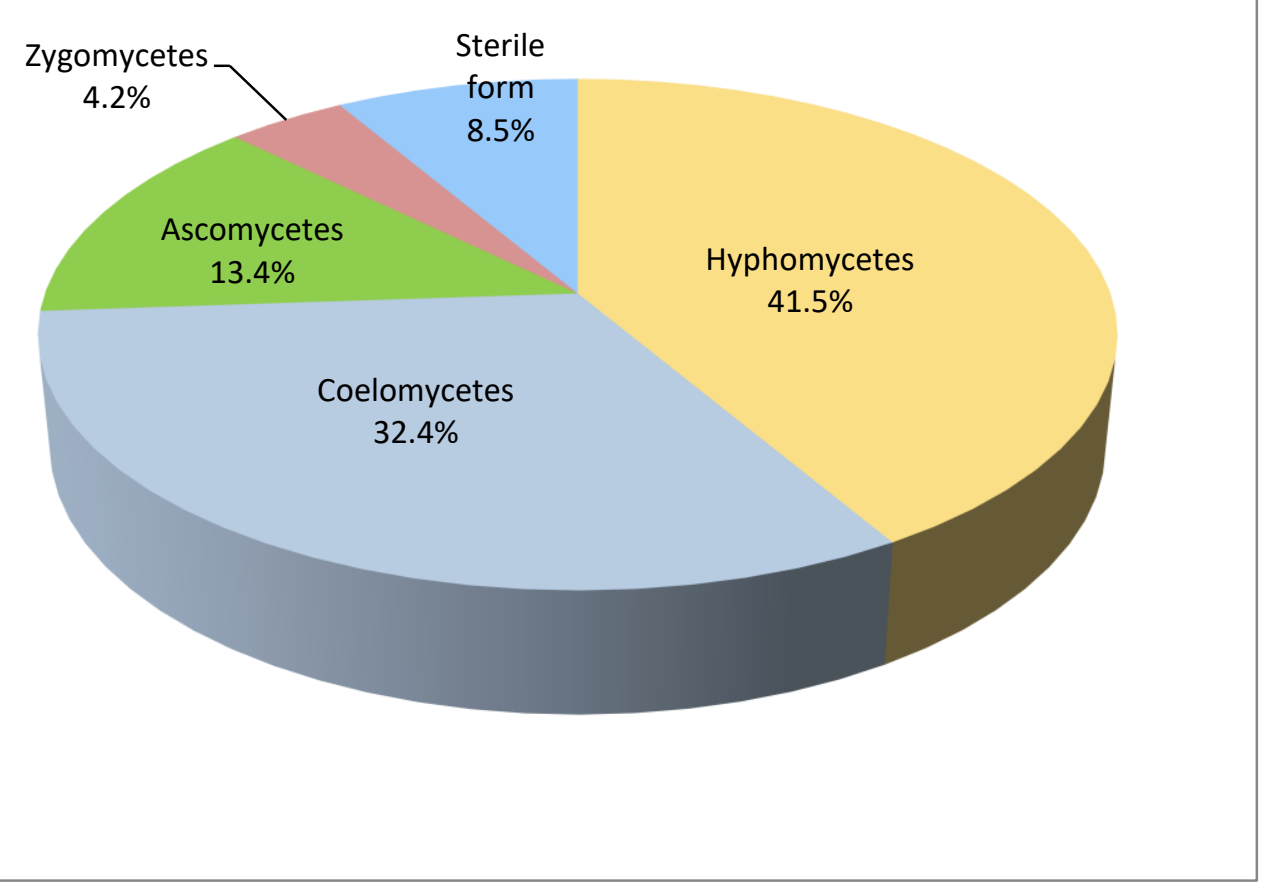

Fig. 1 - Relative Frequency of different groups of endophytic fungal isolates from Couroupita guianensis

moniliformae was $10 \%$ in leaves that gradually decreased in to $8.3 \%$ and $5 \%$ in stem and bark respectively whereas the colonization frequency of Fusarium oxysporum was 5\% alike in leaf stem and bark tissues. In Scytalidium acidophilum, the highest colonization frequency was reported in leaf $(15 \%)$ followed by bark (10\%) and stem (8.3\%). The colonization frequency of Botryodiplodia theobromae was $13.3 \%$ in leaf, $11.7 \%$ in bark and $8.3 \%$ in stem.

The isolates of Colletotrichum spp. were reported only in stem, among them the colonization frequency of Colletotrichum dematium was 3.3\%, Colletotrichum falcatum was $10 \%$ and Colletotrichum truncatum was 5\%. In Phyllosticta hymanaeae, the colonization frequency was $11.7 \%$ in leaf, $8.3 \%$ in stem and 5\% in bark tissues. The colonization frequency of Mycosphaerella sp. was $15 \%$ as maximum in leaf and $8.3 \%$ in stem and bark respectively whereas the colonization frequency of Mucor racemosus was found to be $5 \%$ in leaf and bark respectively and absent in stem. In sterile form, the colonization frequency was $8.3 \%$ in stem, $6.79 \%$ in leaf and $5 \%$ in bark tissues of $C$. guianensis (Table 2 \& Fig. 2).

Among the fungal isolates, Botryodiplodia theobromae was identified to be dominant species $(17.5 \%)$ in bark tissue, Scytalidium acidophilum and Mycosphaerella sp. were found to be the dominant endophytic fungi inthe tissue of leaf (15\%) and Cladosporium cladosporioides and Colletotrichum falcatum were observed as the dominant endophytic fungal isolates (12.5\%) in stemof C. guianensis (Table 2 \& Fig. 3).

The colonization and isolation rates of endophytic fungi in leaf were higher followed by stem and bark tissues in the present study. The high range of colonization rates $(55 \%-80 \%)$ of endophytic fungi were obtained in the present study. The highest colonization rate of $80 \%$ was found in leaf and the lowest colonization rate of $55 \%$ was acquired in bark tissues (Table $3 \&$ Fig. 4). The isolation rates of endophytic fungi were recorded as $0.7-0.9$ in which the low rate of isolation (0.7) was found in bark and high rate of isolation (0.9) was recorded in leaf (Table $3 \&$ Fig. 5). 


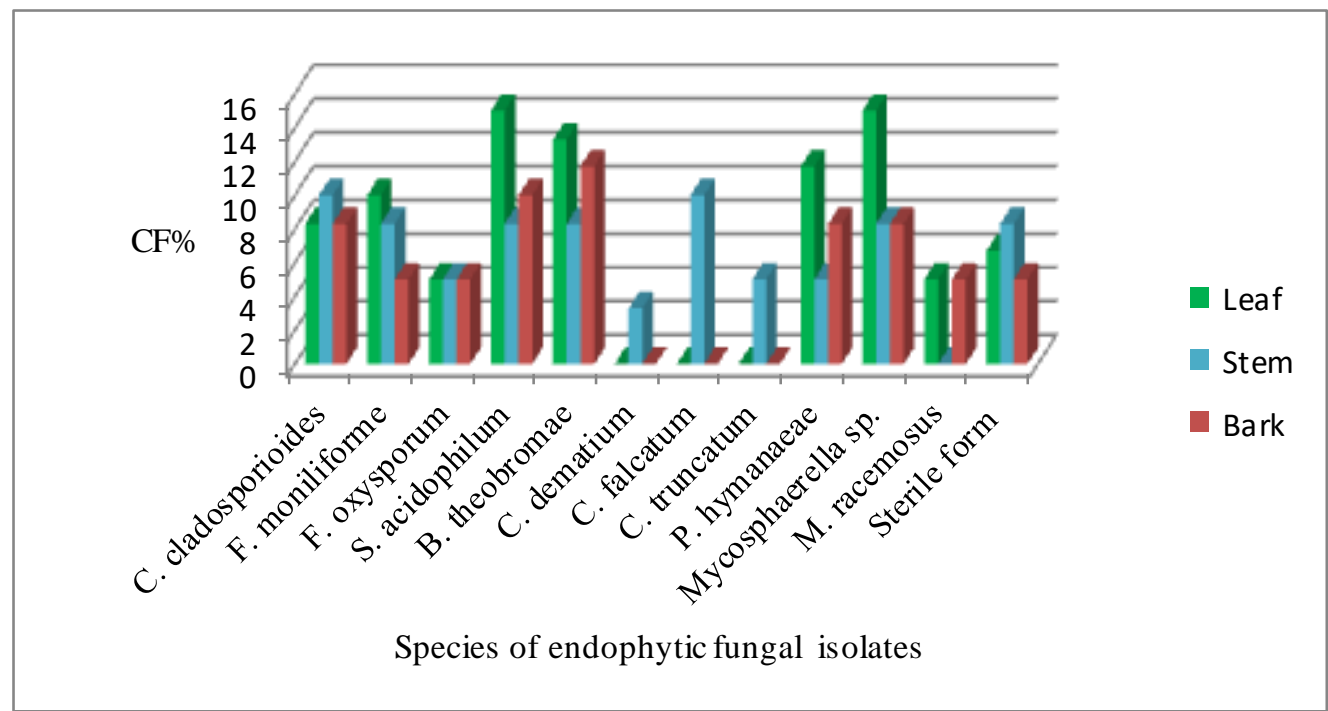

Fig. 2 - Colonization Frequency (CF \%) of Endophytic Mycoflora in different parts of Couroupita guianensis

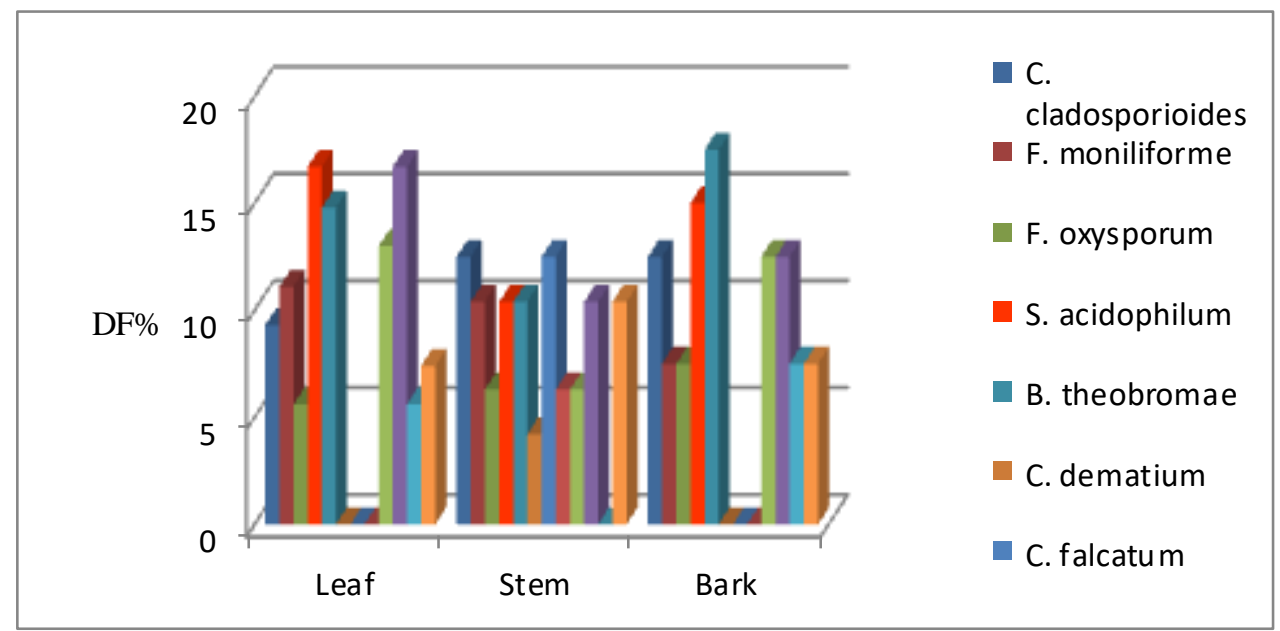

Fig. 3 - Dominant Endophytic Fungi (DF \%) isolated from leaf, stem and bark tissues of Couroupita guianensis

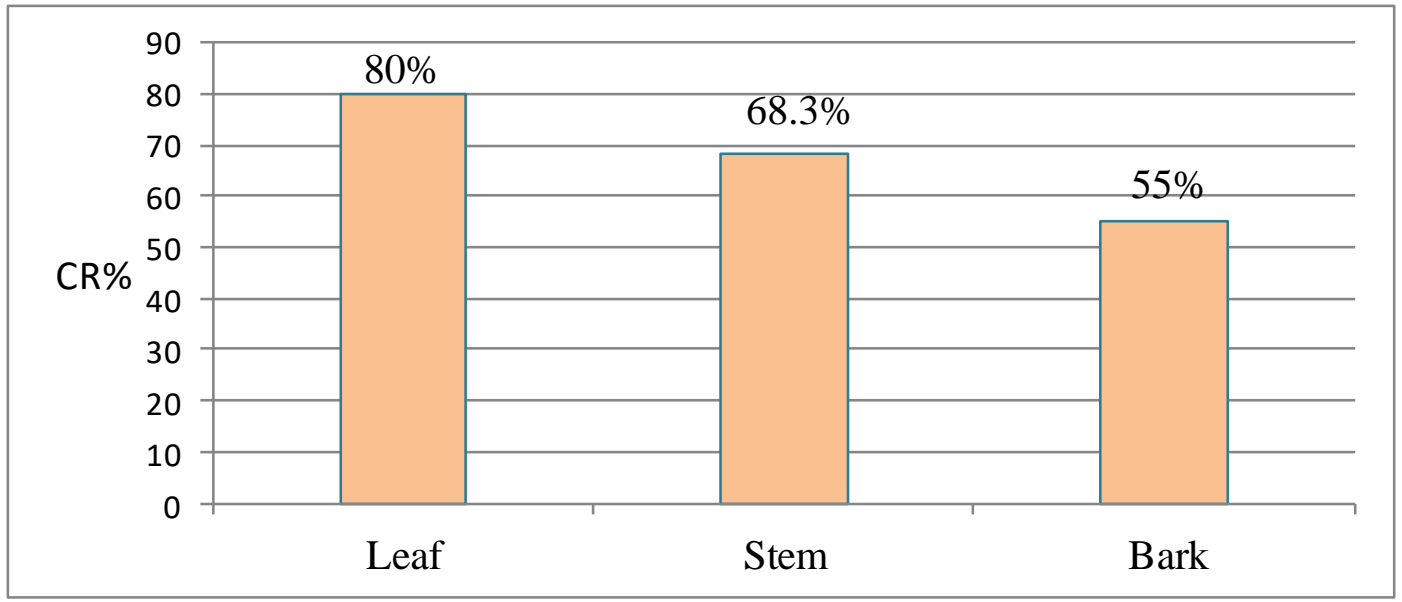

Fig. 4 - Colonization Rate (CR \%) of endophytic fungal isolates from leaf, stem and bark tissues of Couroupita guianensis 


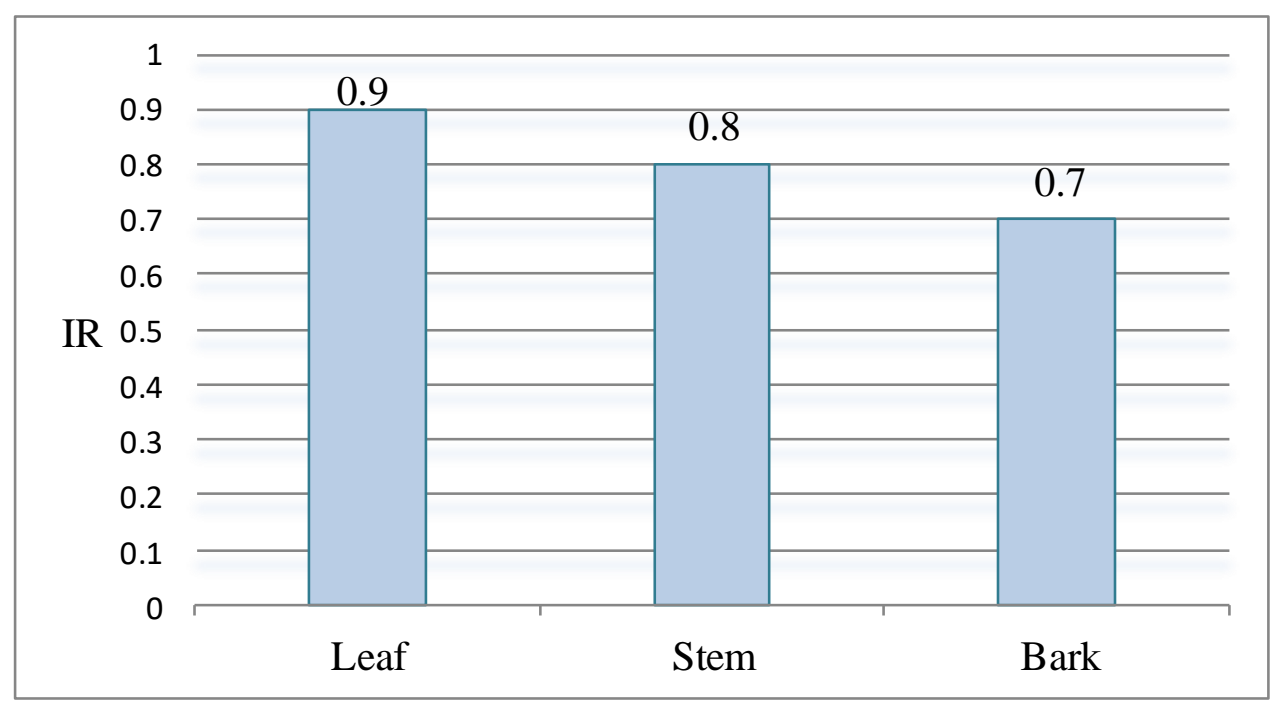

Fig. 5 - Isolation Rate (IR) of endophytic fungal isolates from leaf, stem and bark tissues of Couroupita guianensis

Table 1 - Isolates and Relative Frequency (RF \%) of endophytic fungi from Couroupita guianensis

\begin{tabular}{|c|c|c|c|c|c|c|}
\hline \multirow[t]{2}{*}{$\mathbf{S}$} & \multirow{2}{*}{ Fungal groups } & \multirow{2}{*}{ Endophytic fungi } & \multicolumn{3}{|c|}{ Number of isolates } & \multirow{2}{*}{$\begin{array}{l}\text { RF } \\
(\%)\end{array}$} \\
\hline & & & Leaf & Stem & Bark & \\
\hline 1 & \multirow{4}{*}{ Hyphomycetes } & Cladosprium cladosporioides & 5 & 6 & 5 & \multirow{4}{*}{41.5} \\
\hline 2 & & Fusarium moniliforme & 6 & 5 & 3 & \\
\hline 3 & & Fusarium oxysporum & 3 & 3 & 3 & \\
\hline 4 & & Scytalidium acidophilum & 9 & 5 & 6 & \\
\hline 5 & \multirow{5}{*}{ Coelomycetes } & Botryodiplodia theobromae & 8 & 5 & 7 & \multirow{5}{*}{32.4} \\
\hline 6 & & Colletotrichum dematium & -- & 2 & -- & \\
\hline 7 & & Colletotrichum falcatum & -- & 6 & -- & \\
\hline 8 & & Colletotrichum truncatum & -- & 3 & -- & \\
\hline 9 & & Phyllosticta hymanaeae & 7 & 3 & 5 & \\
\hline 10 & Ascomycetes & Mycosphaerella sp. & 9 & 5 & 5 & 13.4 \\
\hline 11 & Zygomycetes & Mucor racemosus & 3 & -- & 3 & 4.2 \\
\hline 12 & Sterile form & Sterile form & 4 & 5 & 3 & 8.5 \\
\hline & & Total & 54 & 48 & 40 & 100 \\
\hline
\end{tabular}


Table 2 - The Colonization frequency (CF \%) and Dominant Endophytic Fungi (DF \%) isolated from leaf, stem and bark tissues of Couroupita guianensis

\begin{tabular}{|l|l|c|c|c|c|c|c|}
\hline \multirow{2}{*}{ SI } & \multirow{2}{*}{ No } & \multirow{2}{*}{ Endophytic Fungi } & \multicolumn{2}{|c|}{ Leaf (\%) } & \multicolumn{2}{c|}{ Stem (\%) } & \multicolumn{2}{c|}{ Bark (\%) } \\
\cline { 3 - 8 } 1 & CF & DF & CF & DF & CF & DF \\
\hline & $\begin{array}{l}\text { Cladosprium } \\
\text { cladosporioides }\end{array}$ & 8.3 & 9.3 & 10 & 12.5 & 8.3 & 12.5 \\
\hline 2 & Fusarium moniliforme & 10 & 11.1 & 8.3 & 10.4 & 5 & 7.5 \\
\hline 3 & Fusarium oxysporum & 5 & 5.6 & 5 & 6.3 & 5 & 7.5 \\
\hline 4 & Scytalidium acidophilum & 15 & 16.7 & 8.3 & 10.4 & 10 & 15 \\
\hline 5 & Botryodiplodia theobromae & 13.3 & 14.8 & 8.3 & 10.4 & 11.7 & 17.5 \\
\hline 6 & Colletotrichum dematium & -- & -- & 3.3 & 4.2 & -- & -- \\
\hline 7 & Colletotrichum falcatum & -- & -- & 10 & 12.5 & -- & -- \\
\hline 8 & Colletotrichum truncatum & -- & -- & 5 & 6.3 & -- & -- \\
\hline 9 & Phyllosticta hymanaeae & 11.7 & 13 & 5 & 6.3 & 8.3 & 12.5 \\
\hline 10 & Mycosphaerella sp. & 15 & 16.7 & 8.3 & 10.4 & 8.3 & 12.5 \\
\hline 11 & Mucor racemosus & 5 & 5.6 & -- & -- & 5 & 7.5 \\
\hline 12 & Sterile form & 6.7 & 7.4 & 8.3 & 10.4 & 5 & 7.5 \\
\hline & Total & 90 & & 79.8 & & 66.6 & \\
\hline
\end{tabular}

Among the parts of plant, the stem possessed the maximum diversity of endophytic fungi (Shannon -Wiener Diversity $(\mathrm{H})$ : 2.35) followed by bark $(\mathrm{H}: 2.15)$ and leaf $(\mathrm{H}: 2.12)$. The Evenness index was highest and similar in stem and bark (0.95) and lowest in leaf (0.93). The result of Simpson Diversity Index (1 - D) revealed that the stem exhibited the maximum abundance of endophytic fungi (0.90) followed by bark (0.88) and leaf (0.87) of $C$. guianensis (Table 3$)$.

Table 3 - The Colonization Rate (CR \%), Isolation Rate (IR) and Diversity Indices of Endophytic Mycoflora in Couroupita guianensis

\begin{tabular}{|l|l|l|l|c|l|l|l|}
\hline Sourc & $\begin{array}{l}\text { No. of } \\
\text { segments } \\
\text { colonize } \\
\text { e bor of } \\
\text { fungi }\end{array}$ & $\begin{array}{l}\text { No. } \\
\text { Fungal } \\
\text { Isolates }\end{array}$ & $\begin{array}{l}\text { CR } \\
(\%)\end{array}$ & IR & $\begin{array}{l}\text { Shannon } \\
- \text { Wiener } \\
\text { Diversity } \\
\text { Index (H) }\end{array}$ & $\begin{array}{l}\text { Evenness } \\
\text { Index }\end{array}$ & $\begin{array}{l}\text { Simpson } \\
\text { Diversity } \\
\text { Index } \\
(\mathbf{1 - D})\end{array}$ \\
\hline Leaf & 48 & 54 & 80 & 0.9 & 2.12 & 0.93 & 0.87 \\
\hline Stem & 41 & 48 & 68.3 & 0.8 & 2.35 & 0.95 & 0.90 \\
\hline Bark & 33 & 40 & 55 & 0.7 & 2.15 & 0.95 & 0.88 \\
\hline
\end{tabular}




\section{Discussion}

Endophytes may increase host fitness in harsh environments (Redman et al. 2002). This is especially true of plants in arid environments (Faeth \& Hammon 1997). The sacred trees are medicinally important and they are preserved and protected by the local people on religious basis. Medicinal plants are reported to harbour endophytes (Strobel 2002) and have a capacity to protect their host from infectious agents and also provide adaptability to survive in adverse conditions. Many studies have shown that some medicinal properties of plants may be due to endophytic fungi living inside the plants (Azevedo et al. 2002). Endophytic fungi from medicinal plants could be a rich source of functional metabolites (Huang et al. 2008). Endophytes are now considered as an outstanding source of bioactive natural products, because they occupy unique biological niches as they grow in so many unusual environments (Strobel \& Daisy 2003).

In this study, a tropical forest sacred tree Couroupita guianensis from an unusual semi-arid region, yielded 142 endophytic fungal isolates from 180 samples of leaf, stem and bark tissue segments. Most of the fungal isolates belonged to hyphomycetes and coelomycetes in which hyphomycetes were predominant $(41.5 \%)$ over other fungal classes. Such dominance of hyphomycetes as endophytes has also been reported from several plants such as Azadirachta indica and Terminalia arjuna (Mahesh et al. 2005) and also both in leaf and bark tissues of several plants species (Maheswari \& Rajagopal 2013). The dominance nature of hyphomycetes may be attributed to their ability to colonize the host rapidly by producing abundant asexualspores and most fungi of this class occur as phylloplane flora but they are capable of penetrating the superficial layers of leaf and grow as endophyte, suggesting that phylloplane fungi might have adapted to endophytic mode of life to overcome adverse environmental conditions (Cabral et al. 1993).

The isolated two genera Colletotrichum and Phyllosticta are ubiquitous endophytes and have been reported from several plant hosts (Suryanarayanan et al. 2002) in which Colletotrichum sp. are the most frequently encountered endophytic fungi (Photita et al. 2005) that may be either host specific or generalist (Farr et al. 1989) and the remaining genera such as Cladosporium in Azadirachta indica (Tejesvi et al. 2006), Coffea arabica (Oliveira et al. 2014), Fusarium in Murraya koenigii (Suradkar et al. 2014), Ocimum sanctum (Banerjee et al. 2009), Botryo diplodia in Terminali aarjuna (Tejesvi et al. 2005), Mucor in Vitex negundo (Desale \& Bodhankar 2013), Mycosphaerella in Achyranthes bidentata (Bing-Da Sun et al. 2013) and Scytalidium in the leaves of Plumeria rubra (Suryanarayanan \& Thennarasan 2004) were also reported as cosmopolitan endophytes.

Endophytic fungi may inhabit all available tissues, but the leaves of tropical plants are densely colonized by endophytes (Suryanarayanan et al. 2002). All the isolated endophytic fungi showed their preference for specific tissue. Among 142 endophytic fungal isolates, 54 isolated from leaves, 48 isolated from stem and 40 isolated from bark tissue of $C$. guianensis. This results shown that more endophytic fungi could be isolated from leaves than stem and bark and also allied with Gangadevi \& Muthumary (2007). The colonization rate (80\%) and isolation rate (0.9) of endophytic fungi in leaf were higher in the present study this result was correlated with Kumar \& Hyde (2004) in Tripterygium wilfordii. Maheswari \& Rajagopal (2013) were of the opinion that high colonization of endophytes in leaf tissue may be due to their anatomical structure and supply of nutrient elements on which the endophyte depends.

Although, endophytic fungi have been recovered from almost all aerial tissues, some of them show organ and tissue specificity. In this study, more endophytic isolates of Fusarium, Scytalidium, Botryodiplodia and Mycosphaerella were obtained from leaves than in the stem and bark; Cladosporium was isolated more from stem than in the leaves and bark. Endophytic Colletotrichum exhibited organ and tissue specificity that was only isolated from the stem. The isolates of Mucor were reported in the tissues of leaf and bark and not in stem. Petrini et al. (1992) reported that organ specificity of endophytic fungi is due to adaptation to particularmicro-ecological and physiological conditions present in a particular organ.

The colonization of the endophytic fungi is ubiquitous yet selective in nature. Okane et al. (1998) reported that the composition and frequency of colonization related with the place and the 
host condition and also differs within the tissue or organs of a host plant (Kumar \& Hyde 2004). However, usually one or a few fungal species dominate in a host plant (Rajagopal et al. 2010). In this study, the overall colonization frequency of endophytic fungal isolates in leaf was found to be $90 \%$ as highest when compared to stem and bark tissue. The fungal isolates Scytalidium acidophilum and Mycosphaerella sp. showed the highest colonization frequency of $15 \%$ and also they found to be the dominant endophytic fungi $(16.7 \%)$ in leaf. The endophytic fungi Cladosporium cladosporioides and Colletotrichum falcatum were exposed the highest colonization frequency of $10 \%$ and also observed as the dominant isolates (12.5\%) in the tissues of stem. In bark tissues of $C$. guianensis, Botryodiplodia theobromae was identified to be the dominant species $(17.5 \%)$ and the colonization frequency was $11.7 \%$ as reported as highest.

The Shannon-Weiner diversity index was employed to evaluate and compare the diversity of fungi community between different parts in which the stem possessed the maximum diversity of endophytic fungi (Shannon - Wiener Diversity (H): 2.35) followed by bark (H: 2.15) and leaf (H: 2.12). The Evenness index was similar (0.95) in stem and bark and that was closely related with leaf (0.93). The results of Simpson Diversity Index (1-D) revealed that the differences of the abundances of endophytes in leaf, stem and bark tissues were not significant (stem (0.90)>bark (0.88)>leaf (0.87).

A rich diversity of endophytic fungal genera in $C$. guianensis was observed in the present study. The endophytic mycodiversity in the study area was high and they were distinctly associated with host plant parts (leaf $>$ stem $>$ bark). The hyphomycetes were predominant over other fungal classes. In Coelomycetes, Colletotrichum exhibited organ specificity. This study demonstrates that the sacred tree $C$. guianensis is one of the rich ecological niches for endophytic fungi in leaf, stem and bark tissues Eventhough the sacred tree grew in a semi-arid region of tropics.

\section{References}

Anisworth GC, Sparrow KF, Sussman AS. 1973 - The fungi, an advanced treatise, Edition Vol.IV (A), a taxonomic review with keys ascomycetes and fungi imperfecti, Academic Press, New York, pp.1621.

Arnold AE, Maynard Z, Gilbert G, Coley PD et al. 2000 - Are tropical fungal endophytes hyperdiverse? Ecol Letters 3, 267-274.

Azevedo JL, Maccheroni WJR, Araujo WL, Pereira JO. 2002 - Microrganism Osendofíticos eseupapelem plant as tropicais. In: Serafini la, barros nm, azevedojl (Eds), biotecnologia: avanços Na agricultura e naagroindústria. Caxias do sul: edusc. 233-268.

Bacon CW, White JF. 2000 - Microbial Endophytes. Marcel Deker, NewYork, USA.

Bandara WMM.S, Seneviratne G, Kulasooriya SA. 2006 - Interaction among endophytic bacteria and fungi; Effects and potentials. J Biosci 31, 645-650.

Banerjee D, Manna S, Mahapatra S, Pati BR. 2009 - Fungal endophytes in three medicinal plants of Lamiaceae. Acta Microbial Immunol Hungariea 56, 243-250.

Bing-Da Sun, Amanda-Juan Chen, Wei-Wei Gao1, Yu-Guang Zhou et al. 2013 -Endophytic fungi associated with the medicinal plant, Achyranthes bidentata Blume (Amaranthaceae). Afr J Microbial Res 7, 1357-1365.

Cabral D, Stone J, Carroll GC. 1993 - The internal mycoflora of Juncus spp.: microscopic and cultural observation of infection patterns. Mycological Research 97, 367-376.

Desale, Bodhankar MG. 2013 - Antimicrobial Activity of Endophytic Fungi Isolated from Vitex negundo Linn. Int J Curr Microbiol App Sci 2, 389-395.

Faeth SH, Hammon KE. 1997 - Fungal endophytes in oak trees: Long-term patterns of abundance and associations with leaf miners. Ecology 78, 810-819.

Farr DF, Bills GF, Chumuris GP, Rossman AY. 1989 - Fungi on Plants and Plant Products in the United States.APS Press, Minnesota, U.S.A. 816-837. 
Gangadevi V, Muthumary J. 2007 - Endophytic fungal diversity from young, mature and senescent leaves of Ocimum basilicum L. with special reference to taxol production. Indian J Sci Technol 1, 1-15.

Gond SK, Verma VC, Kumer V, Kharwar RN. 2007 - Study of endophytic fungal community from different parts of Aegle marmelos Correae (Rutaceae) from Varanasi (India). World J Microbiol Biotechnol 23, 1371-1375.

Hallman J, Berg G, Schulz B. 2007 - Isolation procedures for endophytic microorganisms. Springer Brelin Heidelberg, New York.

Huang WY, Cai YZ, Hyde KD, Corke H et al. 2008 - Biodiversity of endophytic fungi associated with 29 traditional Chinese medicinal plants. Fungal Diversity 33, 61-75.

Jayapal J, Tangavelou AC, Panneerselvam A. 2014 - Studies on the Plant diversity of Muniandavar Sacred Groves of Thiruvaiyaru, Thanjavur, Tamil Nadu, India. Hygeia :: journal for drugs and medicines 6, 48-62.

Kumar DSS, Hyde KD. 2004 - Biodiversity and tissue-recurrence of endophytic fungi in Tripterygiumwilfordii. Fungal Diversity 17, 69-90.

Mahesh B, Tejesvi MV, Nalini MS, Prakash HS et al. 2005 - Endophytic mycoflora of inner bark of Azadirachta indica Juss. Curr Sci 88, 218-219.

Maheswari S, Rajagopal K, 2013 - "Biodiversity of endophytic fungi in Kigelia pinnata during two different Seasons. Current Science 104, 515-518.

Okane I, Nakagiri A, Ito T. 1998 - Endophytic fungi in leaves of ericaceous plants. Can J Bot 76, 657-663.

Oliveira RJV, Souza RG, Lima TEF, Cavalcanti MAQ. 2014 - Endophytic fungal diversity in coffee leaves (Coffea arabica) cultivated using organic and conventional crop management systems. Mycosphere 5, 523-530, Doi 10.5943/mycosphere/5/4/4.

Petrini O; Stone J, Carroll FE. 1982 - Endophytic fungi in evergreen shrubs in western Oregon: A preliminary study. Canadian Journal of Botany 60: 789-796

Petrini O, Fisher PJ. 1988 - A comparative study of fungal endophytes in xylem and whole stems of Pinus sylvestrisand Fagus sylvatica. Transactions of the British Mycological Society 91, 233-238.

Petrini O. 1991 - Fungal endophytes of tree leaves. In: Microbial Ecology of Leaves (eds. J. Andrew and S. Hirano). Springer, Berlin Heidelberg, New York: 179-197.

Petrini O, Sieber TN, Toti L, Viret O. 1992 - Ecology, metabolite production, and substrate utilization in endophytic fungi. Nat Toxins 1, 185-196.

Photita W, Lumyong P, Hyde KD. 2001 - Endophytic fungi of wild banana (Musa acuminata) at DoiSuthep-Pui National Park, Thailand. Mycological Research 105, 1508-1513.

Photita W, Lumyong S, Lumyong P, McKenzie EHC et al. 2004 - Are some endophytes of Musa acuminate latent pathogens? Fungal Diversity 16, 131-140.

Photita W, Taylor PWJ, Ford R, Hyde KD et al. 2005 - "Morphological and molecular characterization of Colletotrichum species from herbaceous plants in Thailand," Fungal Diversity 18, 117-133.

Rajagopal R, Kalavathy S, Kokila S. 2010 - "Diversity of fungal endophytes in few medicinal herbs of southern India," Asian Journal of Experimental Biological Sciences 1, 415-418.

Redman RS, Sheehan KB, Stout RG, Rodriguez RJ et al. 2002 - Thermotolerance generated by plant/fungal symbiosis. Science 298, 1581.

Saikkonen K, Saari S, Helander M. 2010 - Defensive mutualism between plants and endophytic fungi? Fungal Diversity 41, 101-113.

Savinaya MS, Sangamesh S Patil, Narayana J, Krishna V. 2016 - Traditional medicine knowledge and diversity of medicinal plants in Sharavathi valley region of central Western Ghats. International Journal of Herbal Medicine 4, 124-130.

Staniek A, Woerdenbag HJ, Kayser O. 2008 - Endophytes: exploiting biodiversity for the improvement of natural product-based drug discovery. J Plant Interact 3, 75-93.

Strobel GA. 2002 - Microbial gifts from rain forests. Can J Plant Pathol, 24, 1420. 
Strobel GA, Daisy B. 2003 - Bioprospecting for microbial endophytes and their natural products microbial, Microbiol. Microbiology and Molecular Biology Review 67, 491-502.

Suradkar KP, Hande DV, Kadu SR. 2014 - Seasonal diversity of endophytic fungi from ten medicinal plants. Int J Curr Microbiol App Sci. 3, 260-265.

Suryanarayanan TS, Murali TS, Venkatesan G. 2002 - Occurrence and distribution of fungal endophytes in tropical forests across a rainfall gradient. Canadian J Botany. 80, 818-826.

Suryanarayanan TS, Thennarasan S. 2004 - Temporal variation in endophyte assemblages of Plumeria rubra leaves. Fungal Diversity 15, 197-204.

Tejesvi MV, Mahesh B, Nalini MS, Prakash HS et al. 2005 - Endophytic fungal assemblages from inner bark and twig of Terminalia arjuna W.A. (Combretaceae). World Journal Microbiology Biotechnology 21, 1535-154.

Tejesvi M, Mahesh B, Nahini MS, Prakash HS et al. 2006 - Fungal endophytes assemblages from ethanopharmaceutically importance medicinal trees. Can J Microbiol. 52, 427-435.

Tejesvi MV, Kajula M, Mattila S, Pirttilä AM. 2011 - Bioactivity and genetic diversity of endophytic fungi in Rhododendron tomentosum Harmaja. Fungal Diversity 47, 97-107. 